Journal of Humanities and Social Sciences Studies (JHSSS)

ISSN: 2663-7197

DOI: 10.32996/jhsss

Journal Homepage: www.al-kindipublisher.com/index.php/jhsss

\title{
Krausism in Spain Beyond Philosophy: Religious Tolerance, Social Harmony, Political Reformism and Modern Pedagogy
}

\author{
Gonzalo Capellán \\ Associate Professor of Contemporary History, Department of Humanities - Universidad de La Rioja, Spain \\ $\square$ Corresponding Author: Gonzalo Capellán, E-mail: gonzalo.capellan@unirioja.es
}

\begin{abstract}
ARTICLE INFORMATION ABSTRACT
Received: 08 October 2021

Accepted: 14 November 2021

Published: 17 December 2021

DOI: 10.32996/jhsss.2021.3.12.3

\section{KEYWORDS}

Krausism, Social reform, Democracy, Republicanism,

Krause's philosophy had a deep and long influence in Spain, where krausism went beyond academia to turn their ideas into reality by means of different associations and institutions. The reception of krausean thought took place in a really hostile context, especially due to the rejection by intransigent Catholicism that vilified Spanish krausism in terms of Religion, morals, politics and education. Despite that fact, krausism proved to be very influential in social theory, politics and education from the second half of the $19^{\text {th }}$ century to the outbreak of the Spanish Civil War in 1936. This work is a summary presentation, a revisitation and an updated account of the history of krausism in Spain (with some references to Latin America) focusing on íts practical dimension.
\end{abstract}

Religion, Philosophy, Education,

Science, Spain, Latin America.

\section{Introduction}

\subsection{History of Spanish Krausism revisited}

My fundamental objective with this brief paper is to provide an updated and synthetic presentation of the impact and consequences of Krause's philosophy in Spain (with occasional reference to Latin America).

To this end, I shall focus on the fields where Krausist philosophy exercised a more practical influence: politics, religion, education and social reform. This practical and institutional impact in all spheres of life over a long period stretching from 1860 to 1936 is one of the singular characteristics of Krausism in Spain compared with other places in Europe and Latin America. The very existence of Krausism, understood as a broad group of "intellectuals" with a particular identity (internally and externally), is a differential trait in the Spanish case. For example, compared with Latin America, where Krause's ideas circulated via the work of Ahrens, Tiberghien or Spanish authors and where there were a number of Krausists, but no Krausism per se.

In order to organize the presentation - and link it with that of Professor Sonenscher for the case of France -, I shall follow a chronological criterion, differentiating between three phases. First, the initial dissemination of Krause's ideas before 1860, fundamentally through Ahrens's work, Cours de Droit Naturel (and its translations into Spanish). Here it should be noted that the traditional narrative repeated by historiography and which situates the origins of Spanish Krausism in the figure of Julián Sanz del Río and his travel to Germany in 1843 should be amended. The origins of direct knowledge of Krause's philosophy in German and the interest in his ideas can be traced to the Spanish Conservative politician Santiago de Tejada, who undertook a crucial journey to Germany between 1837 and 1839 (Capellán, 2006; Sáez Miguel, 2018).

The second stage begins in 1860 following the translation - not the adaptation- of Krause's Das Urbild des Menschheit into Spanish and its publication (Ureña, 1992) and his System of Philosophy. It was not by chance that the first public debate regarding Krause's ideas took place in that same year, 1860, in the Madrid Athenaeum. But above all with the formation of the first group of young disciples of Sanz del Río who began to publish a series of journals in order to disseminate his new political Ideal, radical liberalismand who would be active participants in the revolution of 1868 (as well as in the political order that followed that revolution).

Copyright: (c) 2021 the Author(s). This article is an open access article distributed under the terms and conditions of the Creative Commons Attribution (CC-BY) 4.0 license (https://creativecommons.org/licenses/by/4.0/). Published by Al-Kindi Centre for Research and Development, London, United Kingdom. 
The third phase began at the end of the so-called Democratic Sexennium (the six years that followed the revolution, 1868-1874) and coincided with the restoration of the Monarchy in Spain (1875-1931), first, and the proclamation of the Second Republic afterwards (1931-1936). During this long period, Krausist ideas would be materialised in different projects and institutions in the sphere of education ("Institución Libre de Enseñanza", Free School, 1876), social reform ("Instituto de Reformas Sociales", 1903) and politics ("Partido Reformista", 1912).

\section{Krausists and krausism, a brief review}

Given that the two main works that have disseminated the general history of Krausism in Spain and Latin America in the Englishspeaking world (López Morillas, The Krausist movement and ideological change in Spain, 1854-1874, Cambridge University Press, 1980; and Carlos Otto Stotzer, Karl Christian Friedrich Krause and His Influence in the Hispanic World, Koln: Böhlau Verlag, 1998) were written over twenty years ago and that research into Krausism has made very significant contributions since then, I shall underline the more novel aspects or those that have not been addressed in classic works. But also, some of the clichés or interpretations of Krausism do not correspond to historical reality. One example is highly illustrative of this last affirmation. "Krausism" and "Krausist" are not only an analytical category coined by the historiography responsible for studying the history of philosophy, political thought, or social sciences. In other words, they are also historical concepts, terms coined in the second half of the Spanish 19th century to identify the group of people and actions inspired by Krause's ideas.

The first recorded use of the adjective "Krausist" to designate a group of young people that had burst onto the Spanish public scene was in 1861. Then the young professor of Philosophy of Law, Francisco de Paula de Canalejas, spoke in what was then the most prestigious cultural institution, the Madrid Athenaeum, of the existence of a "Krausist school". Thus, an anonymous writer (C.P.Y.B.) who was alarmed by the dissemination of Krausist philosophy in France and Belgium published a pamphlet to refute its ideas. He regarded as unacceptable that "such a filthy and egoistic philosophy" was inoculating in the young Spaniards heads and threatening to destroy their character and even the distinctive nature of our nation" (CPYB, 1869; the author believed that the recent decease of Julian Sanz del Río would 'lead to the end of krausism in Spain).

In their private correspondence, the most representative members of this group, such as Francisco Giner de los Ríos and Gumersindo de Azcárate, would indicate that their idea of creating a Free School in 1876 would be regarded as a "Krausist" idea. Meanwhile, the Diccionario de la Real Academia Española incorporated both terms, nouns, and adjectives into its 1883 edition. The definition provided was purely descriptive: Krausism is the philosophical system of Krause; and restricted to philosophy: Krausist: "Krausist philosopher" (RAE, 1883).

But most noteworthy is the fact that upon the very birth of the terms, in the specific discussions of Krause's philosophy held in the Athenaeum in 1860, the antithetical term "anti-krausist" was coined. In other words, the existence since their initial reception in Spain of a majority group that opposed the German philosopher's ideas. This was evidenced by the substantial propaganda campaign against Krausist philosophy and its followers in Spain (Krausists) undertaken by the Catholic press under the name of "The living texts (a long series of articles published in the newspaper El Pensamiento Español between 1862 and 1863) (Vazquez Romero, 1998).

This anti-Krausist propaganda campaign played a key role in presenting Spanish public opinion with a negative concept of Krausism. The name acquired negative connotations associated with the ideas of "German, foreign philosophy" (an idea that survived over time), rationalist, pantheist philosophy, contrary to Religion, the atheist. In a Dictionary of Ecclesiastical Sciences published in the 1880s, the catholic author Polo y Peyrolon wrote the article "Krausism", stating that the deadly sin of krausist philosophy "lays in its pantheism that, in essence, is nothing but atheism" (Polo, 1888, vol. 6: 249). Moreover, krausism was also considered a revolutionary philosophy, which threatened the established order. After the Civil War, the Spanish Krausists were held responsible for being the intellectual inspiration behind the Second Republic proclaimed in 1931.

A pejorative conception reinforced by Menéndez Pelayo's influential work (Historia de los heterodoxos españoles, 1880-1882) where the Krausists, due to their resolute defence of freedom of conscience and religious tolerance, were considered to be the core of modern religious heresy. In this work written from an intransigent Catholic perspective, Krausism was linked to the obscurity of freemasonry (remember that Krause was a mason) and an abstruse and unintelligible language (in reference to the language of the Spanish Krausists, the result of the translation into Spanish of the philosophical concepts of German idealism). The difficulty of such a translation was reinforced by Krause using a "highly technical language". In addition to this, "over the years, he developed an ever more intricate idiom that became increasingly difficult to decode" (Dierksmeier, 2010: 111).

This peculiar language used by Krausists became commonplace and was adversely manipulated in order to slander both their ideas and their followers. That was the case even in remarkable academic acts, like the admission speech at the Spanish Royal Academy delivered by Vicente Barrantes in 1876. In his speech on "The deformities that bring the language and the ideas of modern Krausist 
philosophy," the author said: "Sanz del Río diatribes against the Spanish language are taking as a gospel, and his Germanized and extravagant style has become a role model". As a result -he followed- the Krausists are killing our poor and harmless Spanish language" (Barrantes, 1876). The unintelligible language used by Krausists at the time became a topic. In a pamphlet reproduced by the Mexican newspaper La Voz de México in 1871 there could be read: "the Krausist uses a series of words that I do not understand (nor does he, I am afraid) and I pleaded with him to speak in Spanish. Also, the text at the bottom of the comic strip on Salmerons' life reads as follows: "One day he became a krausist and then started to speak in American English (that is to say, in a language that Spaniards cannot understand; Gedeon, 24 October 1904).

That heresy, freemasonry, and metaphysical language hard to understand in Spain would be repeated as clichés, especially during the early years of Franco's dictatorship (Juliá, 2013).

Compared with that negative vision, the historiographical revision of Krausism initiated in the 1960s emphasized the positive aspects of its contribution to modern Spain. In this vein, a Diccionario de Español para extranjeros published for the first time in 2002 (and reprinted many times) defines "Krausism" as a conciliatory philosophy between rationalism and religious morality. And the term Krausist is conceived, firstly, as a doctrine that advocates reason and tolerance, and secondly, as a group that defended republican ideas. Current historical revision makes it possible to contextualize those disparate visions and add precision to some of these widely accepted general definitions.

\section{Krausism between 1841 and 1860. Ahrens and Santiago de Tejada}

\subsection{Ahrens and the philosophy of law in Spain and Latin America}

There is no doubt that the first and most important contact with Krause's philosophy in the Spanish-speaking world occurred in an indirect fashion via the course lectures in Philosophy offered by one of his German disciples, Heinrich Ahrens, in Brussels and Paris in the 1830s. The courses imparted at the University of Paris in 1834 at the invitation of Guizot (and Cousin), and those he would subsequently offer at the Free University of Brussels had a considerable impact, both among exiles who heard him firsthand and among those who later read the two works born of his lessons: Cours de Psychologie (Paris, 1836-1838; 2 vols) and Cours de Droit Naturel ou de Philosophie du Droit fait d'apres l'etat actuel de cette science en Allemagne (Brussels, 1838).

This was the case in Spain, where his Cours de Droit Naturel was first translated into Spanish in 1841 by Ruperto Navarro Zamorano (Madrid, 2 vols.). In this first Spanish translation, the chapter dealing with Religion was replaced. The Translator explained that: "When Ahrens writes on Religion exceeds the limits of Law Science... presenting ideas which, considering the current state of Spain, would be a serious negligence to disseminate" (Navarro Zamorano, 1841, vol.1, p. X). The success of this work, which provided a basis for the preparation of Spanish jurists until the end of the 19th century, is evidenced by its numerous printings and re-printings between 1841 and 1906 (see table 1)

\begin{tabular}{|c|c|c|c|}
\hline Year & Place & Publishing House & Translator \\
\hline 1841 & Madrid & Boix & Ruperto Navarro Zamorano \\
\hline $1849^{*}$ & Lima (Perú) & & Bartolome de Herrera \\
\hline 1853 & Paris & Rosa y Bouret & \\
\hline 1855 & $\begin{array}{c}\text { Guadalajara } \\
\text { (México) }\end{array}$ & Tipografía de Rodríguez & $\begin{array}{l}\text { Agustín de la Rosa: Refutación del } \\
\text { Curso de Derecho Natural de Ahrens }\end{array}$ \\
\hline 1864 & Madrid & Carlos Bailly-Bailliere & Manuel Maria Flamant \\
\hline 1873 & Madrid & Carlos Bailly-Bailliere & $\begin{array}{l}\text { Pedro Rodríguez Hortelano y Mariano } \\
\text { Ricardo de Asensi }\end{array}$ \\
\hline 1887 & París / México & Librería de Ch. Bouret & $\begin{array}{l}\text { Pedro Rodríguez Hortelano y Mariano } \\
\text { Ricardo de Asensi }\end{array}$ \\
\hline $\begin{array}{c}1889,1890 \\
1891,1893, \\
1906\end{array}$ & Madrid & Bailly-Bailliere & $\begin{array}{l}\text { Pedro Rodríguez Hortelano y Mariano } \\
\text { Ricardo de Asensi }\end{array}$ \\
\hline
\end{tabular}

Table 1. Editions of the book Cours de Droit Naturel in Spanish 
The book was also read in French. Remarkable evidence of this can be found in the French edition of Ahrens' Course used, annotated and summarized by Antonio Maura, who studied law at the University of Madrid from 1868 to 1871 . The book, owned by Maura, who later became Prime Minister of several Spanish conservative governments between 1903 and 1922 , is held in his personal archive (González, 1997).

To the numerous editions in Europe in various languages, the rapid expansion of its influence in Latin America can be added. Ahrens was not only fully aware but also proud of this success, as reflected in his note to the Preface to the second French edition of the Course de droit. Here he -mistakenly- states that the Spanish translation of 1841 has already had two editions [there was only one] and that "My work has been established as University textbook in many countries, even in America" (Ahrens, 1876, "preface", note 1). This successful dissemination of his book in Latin America was initially due to the Spanish translation of 1841, but subsequently with adaptations such as the one by Bartolome Herrera in Peru who reformed the teaching of law in the country and introduced Ahrens's work into the Colegio de San Carlos. The version of Ahrens's Curso introduced by the conservative catholic Herrera, future Justice Minister and Bishop of Arequipa, soon met with the opposition of other Law professors, like José Silva Santiesteban, who in several books on natural law published in 1853 and 1856 attempted to disseminate in Peru the "real Ahrens". Recent studies have shown Ahrens's remarkable influence on political language during the second half of 19th-century Peru (Loayza, 2010)

The publication in Paris and México of a new Spanish translation of Ahrens's work in 1853 helped to increase its circulation in the Spanish-speaking world. They provoked a reaction by representatives of the Catholic Church. He regarded the teaching of his ideas as pernicious in Law Faculties (copies of this edition, reprinted in 1876, are held in Libraries in Argentina, Chile, Uruguay, Bolivia and México). That happened in Mexico, where Canon Agustín de la Rosa published a refutation of the work entitled Cours de Droit Naturel (Guadalajara 1855), a fact that demonstrates the considerable dissemination of the Krausist philosophy of law in Latin America (Sánchez Cuervo 2004).

In Spain, the young Krausists, a large majority of whom were studying law, were educated with Ahrens's Cours, based on which they formed a liberal political-legal ideology within which we can highlight the following points that they incorporated into their thinking and political activity: the idea of the state as the institution responsible for the fulfilment of the law, understood as the provision of conditions in which individuals can achieve their goals in different spheres of life (economic, scientific, religious...); and the idea that people are social beings by nature (humans are naturally sociable) and that via free association can fulfil all their objectives; in other words, without the state having to intervene. Spanish Krausists believed in the self-government of society. They openly refuted the antagonistic (and conflictive) relationship between the individual and the state (as reminded by Spencer in his widespread book The Man vs the State), trying to overcome that opposition by creating a series of intermediate bodies or free associations. Spanish Krausists therefore promoted and became active members of the Association to Abolish Slavery, the association for the Free trade, the Association for the Progress of Sciences, the Association for the Education of Women...

Together with the mentioned principles, krausism stated the very idea of the primacy of the Rule of Law (Rule of Law; taken from the Kantian concept of Reechstaat). Finally, it is worth noting their consideration of forms of government as "incidental details" (a side issue). The Spanish Krausists believed that - according to Ahrens - there was no preference between the classical forms of monarchy or republic. What is important is that society develops while guaranteeing the freedoms and rights of individuals. In other words, that what mattered was not the form of the state, but the content, that society was sovereign in a context of freedom and democracy in keeping with the culture of every people at every historical moment.

But Ahrens's Cours was not the only route via which the Spanish Krausists could access during this initial phase the ideas of Krause, whose works in German were unknown and very hard to find. Writings provided the main route in French, a language and culture with which cultivated Spanish middle classes were very familiar. In this respect, one might mention the pioneering works published by Pascal Duprat in the Revue Independent from January 1844 onwards, which presented Krause's life and Works to the French public, situating the German philosopher among "contemporary socialists" and highlighting the eminently practical dimension of his philosophy (compared with those of Fichte, Schelling o Hegel); The presentation of Jan Jacques Altmeyer's philosophy of history at the University of Brussels (1840) which made it possible to disseminate the key idea already expressed by Lessing and Herder of the union of peoples in the key concept of Humanity; or, above all, the presentation of Krause's social philosophy by Alfred Darimon, whose work was on sale in Spain, as was advertised by various newspapers of the day (for instance, La Iberia, January 25 , 1856). Duprat, too, situated Krause's philosophy in an evolution that transcended the socialist and reformist doctrines of SaintSimón, Cabet or Fourier (This issue has been fully explained by Professor Sonenscher, 2019).

\subsection{Santiago de Tejada, key figure in the origins of Spanish Krausism}

Along with this essential dissemination of Krause's philosophy in the Spanish-speaking world via the work of Ahrens, here we should underline a fundamental factor for Spanish Krausism. The historical context was the civil war, the so-called Carlist War, 
which broke out in Spain in 1833 following the death of King Ferdinand VII. The succession to the throne saw advocates of establishing a modern liberal state headed by his daughter Isabel clash with those who, under the banner, God, Country and King, sought the succession to the throne of his brother Charles who defended the maintenance of political order and social traditions. The advocates of the Isabelline cause initiated a propaganda campaign across Europe, arguing in favour of Isabel's legitimate right to the Spanish crown. One of those who travelled to Germany in 1837 as part of that campaign was the conservative Catholic politician Santiago de Tejada. During his two years there and seeking support for the Isabelline cause in German university circles, he had direct contact with Krause's disciples in Heidelberg and first-hand knowledge of Krause's work.

His personal archives -which in the context of my research into Krausism I unexpectedly found in 2003- are various unpublished manuscripts, including an early translation of Ahrens Curso (previous to the one published in 1841), partial translations of Krause's "Idea of Law" ("Idea del Derecho") and a translation of the contents of the Urbild der Menschheit ("Ideal de la Humanidad"). He translated this into French, which he used in his travel journal while in Germany. All the manuscripts date from between 1837 and 1839. This new documentation, which gave rise to a recently published doctoral thesis on the figure of Tejada (Pablo Sáez, 2018), leads us to reconsider two essential aspects related to the origins of Spanish Krausism.

Firstly, to affirm that the true origins of the interest in Spain in Krause's philosophy were not to be found in the liberal or progressive governments looking for a new alternative philosophy to conservatism, or in the progressive liberals those who supported Sanz del Río trip to Germany, and neither on those who later gave him a professorship at the University of Madrid in 1854. Rafael Orden Jiménez demonstrated in a book published in 2001 that the Conservative government awarded the Chair to Sanz del Río, as well as the crucial role played by Tejada in supporting and guiding Sanz del Río towards Krause's philosophy. Tejada, immersed in defence of the Catholic Church and its land ownership against the liberal policies of land confiscation, found in Krause two fundamental ideas. On the one hand, a philosophy of law deeply inspired by religion placed God at the apex of its system.

In one of his Parliamentary speeches, when discussing a new project of the Constitution, Tejada used Krause's ideas to support both the essential role of religion in human life and the rights of the Catholic Church in Spain (Tejada, 1844). On the other, a defence of Religion as one of man's essential goals in his vital development, which should be protected from state intervention, as its own institution was the Church. And, therefore, a philosophy that could alleviate - in Tejada's interpretation - the harmful effects of the secularisation of society that was well underway at his point in the 19th century.

Secondly, and consequently, one needs to complete the origins of Spanish Krausism, so far focused exclusively on the figure of Sanz del Río, with the essential preliminary step that made Sanz del Río's subsequent activity possible, Tejada's trip to Germany and political contribution. The correspondence between both authors also reveals the support that until the '60s Tejada would continue to offer Sanz del Río. Tejada was during that period a very influential figure amongst Spanish catholic conservatives as well as personally very close to Queen Elisabeth the First.

\section{Krausism in practice: from the Glorious revolution of 1868 to the Free School (1868-1936) 4.1. Politics: from revolution and democratic monarchy (1868) to republican reformism (1912)}

To this wide dissemination of Krause's ideas by his disciples and different presenters of his work, must be added the far-reaching work of Sanz del Río, not only from his Chair at the University of Madrid that was obligatory to all the Spanish doctoral students of the day but also with the translation of Krause's works which he published in 1860. Among these, the Ideal de la Humanidad para la vida stands out on account of its practical nature and social dimension. It was reprinted in 1871, and it was later translated into English by W. Hastie, professor at the University of Glasgow, as The Ideal of Humanity (Edimburgh, T \& T. Clark, 1900). These years witnessed the education of a series of young students who, inspired by Krausism, would defend liberal democratic political ideas and actively participated in the revolution of 1868 , which overthrew the Bourbon dynasty and resulted in a democratic constitution in 1869. The group had been boosted by a series of journals and newspapers in which the main link between the participants was none other than Krausist philosophy: La Razón (1860), Revista Ibérica (1863), La Voz del Siglo (1868), Derecho (1868), Boletín Revista de la Universidad de Madrid (1869), Revista mensual de Filosofía, Literatura y Ciencias de Sevilla (1869), El Correo de España (1872) and later, Boletín de La Institución Libre de Enseñanza (1876).

The most striking aspect of this group and its activity was that it combined the academic sphere of the University, where they continued to disseminate Krausist philosophy with social mobilization and political practice. With good reason, in his classic work Origins of Modern Spain (Cambridge University Press, 1934), J.B. Trend devotes a lengthy chapter to each of these three leading Krausist authors. It is also worth highlighting the public relevance that some of these young men, like Nicolás Salmerón, Francisco Giner de los Ríos or Gumersindo de Azcárate, would acquire between 1868 and the early 20th century.

Perhaps the best expression of the importance that Krausism acquired in Spain during the years of the Democratic Sexenniun was the fact that Salmerón became Secretary of State for Justice in the Spanish Government, and later, when the First Republic 
was proclaimed in 1873, President of the Republic. Some newspaper cartoons published during that period and later reflected the identity of Salmerón as a politician with Krause's philosophy (see figure 1). It should not be forgotten that Salmerón was a Professor of Metaphysics at the University of Madrid and that his doctoral dissertation (1864) was a study of the philosophy of history peaked by the Alliance of Humanity inspired by Krause (Salmerón 2008).

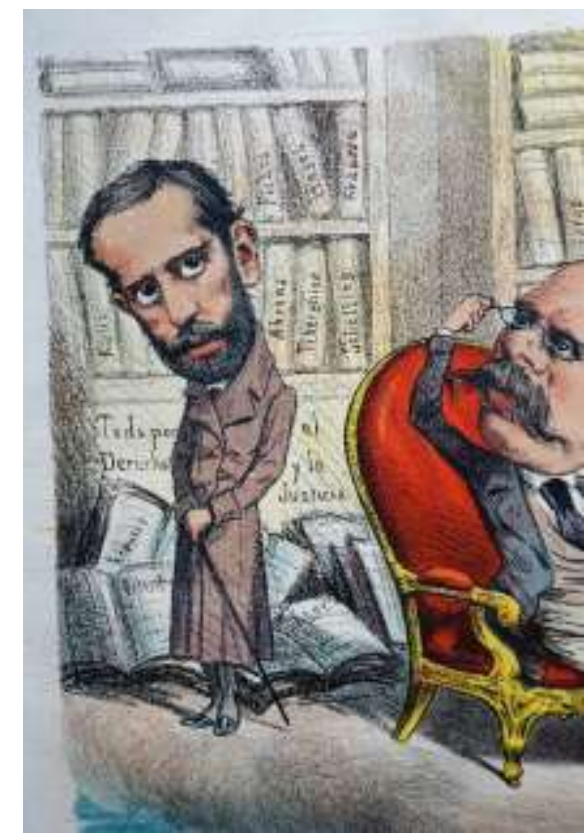

Figure 1. Cartoon of Salmeron surrounded by books (Krause, Hegel, Fichte, Ahrens, Tiberghien...). Source: La Nueva Flaca, 1873 (Author's private collection).

Although it is customary to regard the failure of the First Republic and the end of the Sexennium as a disappointing experience for the young Krausists and to believe that they then abandoned politics, the fact is that neither Salmerón nor Azcárate or other young members of the generation of ' 68 ceased their active participation in Spanish politics after the restoration of the monarchy in 1874. Neither is it true that their ideas were restricted to republicanism and the revolutionary route to power. In fact, when the liberals entered government in Spain in 1881 and initiated a series of progressive reforms (freedom of the press, freedom of association, universal suffrage...), the Krausists abandoned the faction of the Republican party focused on revolutionary action and stood in the elections in order to become Members of the Parliament and attempt to put their ideas into practice from within the political system (they were known as "legalist or legal republicans" to be distinguished from revolutionary ones).

In that context the Krausists created the first great political party of intellectuals in modern Spain, the Partido Centralista (1887) led by Salmerón and Azcárate, as well as Rafael María de Labra, Alfredo Calderón and other leading members of the Institución Libre de Enseñanza. Salmerón later became president of Solidaridad Catalana, a party created in 1906. In 1912, Azcárate, along with Melquiades Álvarez, founded the Partido Reformista, which integrated both the veteran Krausists of the generation of 1868 and young intellectuals of the generation of 1914, philosopher José Ortega y Gasset, acclaimed writer Benito Pérez Galdós, and the well-known Spanish philologist Américo Castro, among others. This party was always prepared to collaborate with the monarchy, provided the parliamentary regime guaranteed every freedom and was open to the peaceful and gradual reforms that would allow it to evolve towards democracy (Suárez Cortina, 2018).

Though their republican militancy was indeed the response to a monarchic government that was reluctant to fully accept modern democracy, the Krausists supported the option of a democratic monarchy at various moments in Spanish history. Consequently, their flexibility in the range of political ideas between monarchy and republic led them in practice to integrate the more moderate wing of Spanish republicanism. This fact contributed to the association of Krausist ideas with this political option (as evidenced by many texts and images of the day).

\subsection{Krausism and social reform}

Along with its political activity, Spanish Krausism would be characterized by its early and considerable sensibility vis-à-vis what was known at the time as the social question or problem. An issue that by the end of the 19th century and with the growing influence of the workers' movement had definitively entered the political agenda of the liberal governments of Europe and America. The 
social problem was largely presented as a conflict between capital (and its representatives, the bosses) and work (represented by workers - the working classes). In that context, various fundamental basic solutions were considered.

On the one hand, economic liberalism proposed the absence of state intervention, convinced that individual forces would eventually resolve the problems generated in the context of the modern market economy and industrial society. At best, the welfare institutions could address the main social problems of the most underprivileged classes. Social Catholicism and the Church also believed that a renewed charity could alleviate the problem of poverty, which they regarded as inherent to society itself.

On the other hand, socialism advocated direct state intervention as the main agent for redistributing wealth. In the Spanish context, by means of profound agricultural reform that would grant land ownership to farmworkers, A solution, also advocated in the United States by Henry George, dared to touch private property, a sacred principle of liberal ideology. But this reform by the state was not even accepted by Marxist socialism, which argued that the solution could only be achieved by force via the proletariat's revolutionary action against the bourgeois state. Marxist socialism considered the relationship between capital and work in terms of conflict of class struggle.

In the light of these prevailing ideas, Krause's social philosophy, and in particular his key concept of harmony, was extremely valuable to Spanish Krausists. Actually, "harmony" became a powerful metaphor able to turn off some key social and political counter-concepts. The concept's original meaning came from Pitagoras' philosophy, as reminded in Ahrens' Curso de Derecho. But along the 19th century, it moved from the field of Natural philosophy (Cosmos), Music and Mathematics (Pythagoras' school) and of Astronomy (Kepler's Harmonices Mundi) to that of Philosophy of history (Krause) Social reform (Owen's New Harmony and Fourier) or Political economy (Bastiat, Harmonies économiques). The harmonic vision of society proved to be a relevant one in Contemporary Spain, where society witnessed several civil wars.

In their quest for the political and social progress of society via a gradual and pacific evolution of reforms, Spanish krausism understood that the relationship between capital and work had to be harmonious (as we know, in Krause's dialectic, every thesisunity- and antithesis- variety- is resolved in harmonic synthesis). Upon the basis of that social harmony, they promoted and collaborated in a series of state institutions that helped improve the lives of the working classes and adopted measures and legislation that protected workers.

The first initiative was that of the Krausist and founder of the Free School, Segismundo Moret. In 1883, he was appointed Secretary of State for the Home Office of the Liberal Government. The so-called "Comisión de Reformas Sociales" (Social Reforms Commission) performed the most important study of workers' living conditions in all the provinces of Spain and every economic sector (industry, mining, agriculture...). That first step was later extended with the creation of the Instituto de Trabajo in 1902 and 1903, the "Instituto de Reformas Sociales" (predecessors of today's Secretary of State for Labour and Social Welfare) (Palacio Morena, 2004).

The Conservative government assigned the presidency of the Institute to Gumersindo de Azcárate in recognition of the key role played by the Krausists in the field of social reform. Azcárate presided over the Institute until he died in 1917 and enjoyed the respect of both workers and bosses, mediating between their conflicting interests, overseeing the adoption of significant measures to reduce extremely long working days, and legislation that protected workers in situations of illness or incapacity. In other words, there was a contribution to the first steps on the path towards the Welfare State in Spain. There was, however, criticism from the ranks of radical republicanism of Azcárate's and the Krausists' collaboration with the government and the Monarchy of Alfonso XIII. Political and social action that contrasts with -and refutes- the image of the Krausist as a wise philosopher, removed from the real world and incapable of practical action, an image so frequently found in Spanish literature of the time.

\subsection{Science and education: The Free School (1876-1936)}

But for the Spanish Krausists, the only truly efficient means of achieving profound reform of society was education. "Educating the new man", as Giner de los Ríos liked to say. As well as their political and social action, the Krausists had focused their efforts on educating the young of Spain at both universities and secondary schools since their early days. During the Democratic Sexennium, they were also pioneers in Spain by introducing Kindergartens and Froebel's ideas on education. As Menéndez Ureña (1992) has correctly observed, Froebel himself acknowledged that Krause's philosophy formed the basis of his pedagogy.

In turn, Giner de los Ríos would claim in an article published in the Bulletin of the Free School in 1879 that Froebels's thought constitutes "the basis for the immediate reform of our current education". During that same period, the Spanish Krausists were pioneers in promoting and developing women's education, first with a series of conferences aimed at a female audience and setting up and running the Association for the Education of Women. As emphasized by another key member of the Free School, Manuel Bartolomé Cossio, there is "an imperative need to erase the existing chasm between men and women's culture" (Cossío, 1890). 
In line with Krause's ideas, they believed that historically only two institutions and in two spheres of life had mankind achieved maturity. First, the Church, as a religious institution, had extended its activity to other areas of society that were not within its competence, such as politics or science. Later, as a legal institution, the state had also overextended its intervention in the lives of individuals. And during that period, the 19th century for them, the time had come for the full development of science, the institution of which was the University.

That attempt to liberate education from the institutions that historically had supervised or controlled it, Church and State, was soon seen as a dangerous and unacceptable endeavour. This was made very clear in 1875, upon the Restoration of the Monarchy in Spain, when the Conservative government expelled the most prominent Krausist professors from universities for advocating their academic freedom and refusing to be forced by the state to teach according to official Monarchic and Catholic principles. For so doing, Salmerón, Giner de los Ríos and Azcárate were arrested and exiled for several months. In these circumstances, the Krausists decided to create a Free School through which they could continue to develop their educational work and, therefore, reform Spanish society. The Free School was created in 1876, and although it initially focused on Higher Education, it subsequently concentrated on Reception, Primary and Secondary Education. Its goal was to offer a "neutral" education, in other words, independent of any political ideology or religious creed, and to provide an integral education employing the most innovative methods and ideas of modern pedagogy. Despite the religious tolerance advocacy of Spanish krausists that held a positive view of Religion (as distinguished from different religious creeds), they were criticized for promoting a secular and godless school (Capellan, 2017).

From the 1880s onwards, the Free School became a laboratory for every educational innovation and the model for the reforms undertaken by liberal governments. There thus followed the creation of other key institutions like the "Museo Pedagógico Nacional" directed by Bartolomé Cossio, the "Junta de Ampliación de Estudios" (Board for Further Training) which enabled young Spaniards to study overseas, the "Instituto Escuela" (School Institution), that aimed to improve teachers training, or the "Residencia de Estudiantes" (Students' Residence) run by Alberto Jiménez Fraud and the "Residencia de Señoritas" (Ladies' Residence) under the supervision of María de Maeztu (García Velasco et al., 2013).

\section{Conclusion. Krausism, Spain and Latin America}

During these final years of the 19th and initial decades of the 20th century, Krausism broadened its horizons and action, now with the Free School, and had a great influence in Latin America. In this sense, various factors were crucial: firstly, the extensive translation in Spain of German and Belgian Krausist texts, making possible their circulation by way of a complement to Ahrens's Curso. Krause's Ideal with two editions in 1860 and 1871, Roeder's works on criminal law, Leonhardi and Tiberghien's works on Religion, or a considerable quantity of this latter author's works that increased his readership in America. This was apparent in another new academic controversy in México in the 1880s with the official adoption of Tiberghien's handbook on Logic (Sanchez Cuervo, 2004).

The translation and dissemination of the main foreign authors in the most diverse scientific disciplines was an essential contribution of Spanish Krausism in its desire to modernize Spain and place it in contact with the international context. Fundamental within this undertaking was the publication from 1876 onwards of its Bulletin, published until 1936 and the longest-lasting and most important Spanish scientific journal during that era. Thus, it also made a decisive contribution to the development of social sciences in late-19th century Spain, addressing sociology, psychology, political science and pedagogy and disseminating the most advanced ideas, texts and authors of the day. But also, experimental sciences, in some fields of which, such as marine biology, the Krausist worked intensively.

Also is worthwhile highlighting the contribution of Manuel Sales y Ferré, Spain's first professor of Sociology, author of the most important work on the history of modern Europe in 1900, blending in his historical sociology Krause's philosophy of history and naturalist evolutionism. Europe in this history is no more than that intermediate stage of the evolution of Humanity, which from the ancient forms of association, family, tribe, village... had evolved to become a nation, a reality that would be transcended, first, by the association of nations, in the Spanish case with Portugal (Iberism) and with the rest of the European continent, and later in the union of the continents in the great alliance of Humanity. A short of humanitarian cosmopolitism that proved to be especially appealing in the context of the Great War (Capellán, 2020). Then, when different countries were seeking ways of international cooperation to guarantee peace, a revitalization of Krauses' philosophy took place. A nice sample were the writings in English by Clay Maccauley intended to widespread Krause's ideas, not only in the USA but also in Japan, where he worked as a unitarian missionary: Krause's League for Human Right and Thereby World Peace (Tokio, 1917; also published as a series of articles in The Japan Times) and Karl Christian Friedrich Krause: heroic pioneer for thought and life (Berkeley, 1925). He first became acquainted with Krause's philosophy while studying Theology at Heidelberg University in the 1870s. 
The second channel that facilitated the dissemination of Krausism in Latin America was the direct contact established between Spanish Krausists and Americans who travelled to Spain at the height of Krausism. One of the most notable cases is that of the Cuban leader José Martí, whose Krausist influences are well known (the influence of Krausism in the Cuban liberal and reformist movement has recently been studied by Delphine Sappez (2016). And also, the Krausists own travels to America together with the dissemination of their texts and ideas. A particularly interesting example of that is Costa Rica, where the Canarian Krausists Valeriano and Juan Fernández Ferrar emigrated and imported the educational model of the Free School (Reyes Ledesma 1994). Studies in this country focused on the works of Giner de los Ríos, whose Principios de Derecho Natural would be adopted as an official text at the Universidad Mayor de Montevideo in 1878 (Gómez-Martínez, 1989). Significant visits included those made by the prestigious Krausist historian Rafael Altamira, who travelled to America for the first time in 1908 and visited Argentina, Uruguay, Chile, Perú, México and Cuba. Altamira published a detailed account of this trip (Altamira, 2008). Adolfo Posada also made significant trips, first when invited to give a course of political law at the Universidad de la Plata in 1910 and subsequently in 1921, delivering numerous conferences in several Latin American countries (Posada, 1911).

This was also the period when Krausism influenced leading politicians in Latin America, some of whom would become presidents of their governments and base some of their policies and reforms on Krausist ideas. Two outstanding and well-studied cases are those of José Batlle y Ordóñez in Uruguay, where he presided over the government on various occasions between 1899 and 1915 (Monreal, 1993) and Hipólito Yrigoyen in Argentina, who was president between 1916 and 1922 (Biagini, 1989). Not to mention the later influence in one of the most important Argentinian political ideologies, radicalism, according to the testimony of President Raul Alfonsin (Alfonsin, 1983).

With this schematic presentation, I hope that I have outlined the importance of Krause's philosophy in Spain and Latin America and the paths, individuals, ideas, and institutions that, between 1840 and 1936, constituted the so-called Spanish Krausism. Together with an update of the topic, I have provided new evidence and findings, such as the key role played by Santiago de Tejada in the original reception of Krause's Philosophy in Spain (not available in the scientific literature produced in the English language so far). Also, this work shows that the great influence of Krause in Spain was not the result of his system of thought but the practical application of some of his ideas, such as social harmony, organicism or Humanity. Finally, this contribution has revealed that for a full understanding of krausism, we should consider the specific historical, cultural and political context of $19^{\text {th }}$ Century Spain.

Funding: This text is part of the work of the Research Group IT615- 13 and the Research Project HAR2017-84032- P, financed by the Basque Department of Education, Universities and Research, and by the Ministry of Science and Innovation, Government of Spain (plus ERDF, EU), respectively.

Acknowledgements: I am grateful to the University of la Rioja Library for the support and help to get some bibliographic references.

Conflicts of Interest: "The authors declare no conflict of interest." "The funders had no role in the design of the study; in the collection, analyses, or interpretation of data; in the writing of the manuscript, or in the decision to publish the results".

\section{References}

[1] Altmeyer, J.J. (1840). Cours de philosophie de l'histoire. Bruxelles : Meline, Cans et Compagnie.

[2] Ahrens, H. (1841): Curso de derecho natural formado con arreglo al estado de esta ciencia en Alemania, Madrid, Boix editor (Traducido y aumentado con notas y una tabla analítica de materias por orden alfabético por Ruperto Navarro Zamorano).

[3] Ahrens, H. (1876). Curso de derecho natural o de filosofía del derecho completado en las principales materias, con ojeadas históricas y políticas. Paris / México: Librería de Bouret e Hijo.

[4] Alfonsín, R. (1983). ¿Qué es el radicalismo? Buenos Aires, Editorial Sudamericana.

[5] Altamira, R. (2008): Mi viaje a América. Oviedo: Universidad de Oviedo.

[6] Barrantes, V. (1876). Deformidades que en el lenguaje y las ideas trae consigo la moderna filosofía krausista. Discursos leídos ante la Real Academia Española. Madrid: Establecimiento Tipográfico de P. Núñez.

[7] Biagini, H.E (1989): Orígenes de la democracia argentina. El trasfondo krausista, Buenos Aires: Ed. Legasa.

[8] Capellán, G. (2006). La España armónica: el proyecto del krausismo español para una sociedad en conflicto. Madrid: Biblioteca Nueva.

[9] Capellán, G. (2017). Ecce homo. Azcárate y la cuestión religiosa en la España contemporánea. Gumersindo de Azcárate. Minuta de un testamento. Madrid: Fundación Giner de los Ríos / Fundación Sierra Pambley.

[10] Capellán, G. (2020). Manuel Sales y Ferré. Un historiador en el siglo de la ciencia. Manuel Sales y Ferre. El advenimiento de la democracia en Europa. Pamplona: Urgoiti Editores.

[11] Cossío, M. B. (1890). Ventajas de la enseñanza mixta. Boletín de la Institución Libre de Enseñanza, 363.

[12] CPYB (1869). Paradoja contra Krause y su discípulo Sanz del Río en el estilo llamado neo-católico. Madrid.

[13] Darimon, A. (1848). Exposition méthodique des principes de l'organisation sociale: théorie de Krause: précédée d'un examen historique et critique du socialismo. Paris : Franck, éditeur. 
[14] Dierksmeier, C. (2010). Krausism, A Companion to Latin American Philosophy. Blackwell.

[15] García V, J. (2013). La Institución Libre de Enseñanza y Francisco Giner de los Ríos: nuevas perspectivas. Madrid: Fundación Giner de Los Ríos and Acción Cultural Española (3 vols.).

[16] Giner de los Ríos, F. (1879) ¿Instrucción o educación? Boletín de la Institución Libre de Enseñanza, 62.

[17] Gómez M, J.L. (1989). El krausismo en Iberoamérica. El krausismo y su influencia en América Latina. Madrid: Fundación Friedrich Ebert/Instituto Fe y Secularidad

[18] González H, M.J. (1997). El Universo conservador de Antonio Maura. Biografía y proyecto de Estado, Madrid: Biblioteca Nueva.

[19] Hastie, W. (1900). The Ideal of Humanity. Edimburgh: T \& T. Clark.

[20] Ledesma R, M. (1994). Krausismo y educación en Costa Rica: La influencia de los educadores canarios: Valeriano y Juan Fernández Ferraz. Tenerife: Universidad de La Laguna.

[21] Loayza, A. (2010). Cambios en el lenguaje político peruano a mediados del siglo XIX: Ahrens y el debate entre los colegios San Carlos y Nuestra Señora de Guadalupe. Actas del conversatorio Sebastián Lorente y Primer Colegio nacional de Nuestra Señora de Guadalupe. Lima.

[22] López M, J. (1980). The Krausist movement and ideological change in Spain, 1854-1874. Cambridge: Cambridge University Press.

[23] Maccauley, C. (1917). Krause's League for Human Rights and Thereby World Peace. Tokio.

[24] Maccauley, C. (1925). Karl Christian Friedrich Krause: heroic pioneer for thought and life. Berckeley.

[25] Menéndez y P, M (1880-1882). Historia de los heterodoxos españoles. Madrid.

[26] Monreal, S. (1993). Krausismo en el Uruguay. Algunos fundamentos del Estado tutor. Montevideo, Universidad Católica del Uruguay.

[27] Orden J, R. V. (2001). Sanz del Río en la Universidad Central: los años de formación (1837-1854). Madrid: Universidad Complutense de Madrid.

[28] Palacio M, J. I. (2004). La reforma social en España: en el centenario del Instituto de Reformas Sociales. Madrid: Consejo Económico y social de España.

[29] Polo P, M. (1886). Krausismo. Diccionario de Ciencias Eclesiásticas. Valencia, VI, 249-257.

[30] Posada, A. G. (1911), En América una campaña; relaciones científicas con América, Argentina, Chile, Paraguay y Uruguay. Imprenta Fortanet.

[31] RAE (1883). Krausismo. Diccionario de la Real Academia Española. Madrid.

[32] Rosa, A. de la (1855). Refutación de la obra titulada Curso de derecho Natural o de Filosofía del derecho formado con arreglo al estado de esta ciencia en Alemania por $\mathrm{H}$. Ahrens. Guadalajara: Tipografía de Rodríguez.

[33] Sáez Miguel, P. (2018). Santiago de Tejada y Santamaría (1800-1877). Biografía política e intelectual de un conservador autoritario. Logroño: IER.

[34] Sánchez C, A. (2004). El krausismo en México. México: Universidad Nacional Autónoma de México.

[35] Salmeron, N. (1864 y 2008). La Historia universal tiende, desde la Edad Antigua a la Edad Media y la Moderna, a restablecer el hombre en la entera posesión de su naturaleza, y en el libre y justo ejercicio de sus fuerzas y relaciones para el cumplimiento del destino providencial de la Humanidad. Santander: Ediciones de la Universidad de Cantabria.

[36] Sappez, D. (2016). El krausismo en la formación del movimiento reformista y liberal en Cuba (siglo XIX). Revista de Indias, Vol. $76,267$.

[37] Sonenscher, M. (2019). Krausism and its legacy. Global Intelectual History, 5 (1), 1-21

[38] Stotzer, C. O. (1998). Karl Christian Friedrich Krause and His Influence in the Hispanic World, Koln: Böhlau Verlag, 1998.

[39] Suárez C, M. (2018). Los caballeros de la razón. Cultura institucionista y democracia parlamentaria en la España liberal. Genueve Ediciones.

[40] Tejada, S. (1844). Discurso del Señor D. Santiago Tejada sobre la reforma de la Constitución. Madrid.

[41] Trend, J.B. (1934). Origins of Modern Spain. Cambridge: Cambridge University Press.

[42] Ureña, E.M, Fernández Fernández, J.L. and Seidel, J. (1992). El "Ideal de la Humanidad" de Sanz del Río y su original alemán. Madrid: Universidad Pontifica de Comillas.

[43] Ureña, E.M (2002). El krausismo alemán: los congresos de filósofos y el krausofröbelismo (1833-1881). Madrid: Universidad Pontifica de Comillas.

[44] Vázquez Romero, J. M. (1998). Tradicionales y moderados ante la difusión de la filosofía krausista en España. Madrid: Universidad Pontificia de Comillas 